\title{
Going (in)conspicuous: antecedents and moderators of luxury consumption
}

\author{
Amélia Maria Pinto da Cunha Brandão ${ }^{1}$ [ Hugo Eduardo Magalhães Barbedo ${ }^{1}$
}

Revised: 16 July 2021 / Accepted: 26 January 2022

(c) The Author(s), under exclusive licence to Springer Nature Limited 2022

\begin{abstract}
As a result of the increasing worldwide luxury expenditure, and consequently, its democratization, consumers in mature markets feel that luxury has lost its uniqueness and exclusivity. Despite academia having deemed conspicuousness and luxury connected, this study intends to determine the main antecedents of (in)conspicuous luxury consumption, and crossculturally analyze both conspicuous and inconspicuous luxury consumption. A partial least square structure equational model was conducted. The data collection framework followed a traditional SEM data collection and consequent analysis. The results revealed that consumer need for uniqueness is an antecedent of inconspicuousness luxury consumption, while cultural capital has a negative effect on conspicuous luxury consumers, mediated by susceptibility to normative influence. Additionally, between Southern European and Central/Eastern European consumers, cultural capital impacts differently on luxury consumption. By adopting a critical view of the nature of luxury, analyzing its conceptual evolution through the ages, and matching it to its current landscape via identifying antecedents of inconspicuous luxury consumption, this study is a steppingstone for luxury consumption research, as it postulates a new understanding of what constitutes luxury consumption, thus opening up new research avenues for academia.
\end{abstract}

Keywords Inconspicuousness $\cdot$ Luxury consumption $\cdot$ Cross-cultural $\cdot$ Cultural capital $\cdot$ PLS-SEM

\section{Introduction}

In emerging markets, luxury is still with intentions of both status-signaling and bringing one's self-image closer to those considered as occupying a more prominent social position, particularly via the display of bold logos (Kaufmann and Manakova 2012). The luxury market has been growing since the 1990s (Wu et al. 2015), with a constant $5 \%$ growth rate until the COVID-19 pandemic (Willersdorf et al. 2020; Montgolfier 2017). The global Luxury goods market is expected to increase from US $\$ 309.6$ billion in 2021 to US $\$ 382.6$ billion in 2025 at a CAGR of 5.4\%. With respect to geography, Asia is expected to witness the highest spending and is followed by Europe, North America, South America, Africa, and Australia and Oceania. The fashion

Amélia Maria Pinto da Cunha Brandão

ameliabrandao@fep.up.pt

Hugo Eduardo Magalhães Barbedo

hugo.magalhaesbarbedo@gmail.com

1 Faculty of Economics and CEF.UP, University of Porto, Porto, Portugal and accessories industry is the most popular category when it comes to gifting or consumer buying.

Such a growing luxury tendency is explained by both economic (increased disposable income) and social factors (increased perception of high-end goods as essential due to personal comparison) (Lewis and Moital 2016). Despite traditional luxury markets still being the main "revenue gatherers" (Delloite 2018), its "new money consumers" (Husic and Cicic 2009), with an increasing purchasing power booming in Middle Eastern and Asian (Delloite 2017) through imitation of traditional consumers, are pushing the industry forward (Cervellon and Shammas 2013; Hudders et al. 2013). The actual luxury spending is increasing, contributing to the one world spread of logos like the Louis Vuitton LV and iconic designs, such as the Burberry plaid (Makkar and Yap 2018b), but at what cost?

In the past, luxury was associated with luxury consumption and conspicuous consumption. However, the theory of the conspicuous model is no longer the main point of reference for the luxury market regarding academics and practitioners. The market has evolved, and consumers no longer seek mere status recognition, but rather look for 
experiential meaningful moments (Loureiro et al. 2020). In fact, the attention has been shifting from "having-to-be" to "owning-to-experience" (Cristini et al. 2017). In contrast to conspicuous consumption, there is now inconspicuous consumption. Inconspicuous consumers prefer to be more discreet and to buy products different from the mass-markets, but are recognized by those with the required level of knowledge (Eckhardt et al. 2015). Hence, the key element of a successful luxury brand is having a strong brand image and identity. Because of this aspect, some of the most valuable brands of the world are luxury ones. It is important to note that luxury consumers first, attached more importance to symbolic dimensions (e.g., status), followed by functional dimensions (e.g., utility) and, presently, the experiential dimension (meaningful experiences).

Thus, traditional markets are responding to this new luxury paradigm by going inconspicuous: luxury no longer equates with conspicuousness (Eckhardt et al. 2015). Despite both academia and institutions having predicted the rise of inconspicuousness (see, e.g., Belk and Wilson, 2015; Job 2015; Wilson 2014; Crain 2010; Eckhardt, 2015), little seems to be known about it. Makkar and Yap (2018a 2018b) and Shao et al. (2019a 2019b) have pioneered inconspicuousness research, steering away from academia's long history of conspicuousness (see, e.g., Kaufmann, Vrontis, and Manakova, 2012; Han et al. 2010; Veblen 1992; Leibenstein 1950). Yet, more inconspicuous luxury consumption research is clearly needed. The present study aims to bridge this academic gap, identifying the drivers for both conspicuous and inconspicuous luxury consumption from the consumer point of view. Accordingly, this research integrates the fragmented knowledge generated by previous research in terms of drivers for conspicuous and inconspicuous luxury. Moreover, this study decouples luxury from conspicuousness, discusses previous findings, and cross-culturally analyze conspicuous and inconspicuous luxury consumption.

The luxury market has been growing constantly since the 1990s (Wu et al. 2015): 2017's 5\% growth rate was expected to be maintained until 2020 (Bain and Company, 2017). This growth tendency in the luxury sector is explained by economic factors like increased disposable income, as well as social factors such as personal comparison to others, which has led people to more and more regard high-end products and goods as essential in their day-to-day lives (Lewis and Moital 2016).

The traditional markets (i.e., US and Western Europe) are still the main sources of luxury revenue in which the industry's largest conglomerates are based, with the top 10 luxury groups currently accounting for $47.2 \%$ of the industry's revenue (Deloitte 2018). However, the industry is being driven by the middle class in the emerging luxury markets (Hudders et al. 2013), e.g., China, the UAE, and Russia (Deloitte 2017). In 2017, Chinese consumer spending on luxury goods grew by $7 \%$ (Sohu, n.d.) and $96 \%$ of Chinese millennials expected that luxury spending would either remain unchanged or increase (KPMG, n.d.). The rising purchasing power in these classes is increasing the actual spending on luxury, leading to the widespread of "loud" logos like those of Louis Vuitton and Gucci, and iconic designs such as Burberry's plaid, throughout the world. This massification of luxury is eroding the uniqueness that traditional consumers pursued. Renowned and extremely influential fashion designers, like Giorgio Armani, are still engraving prominent logos and cues into their designs (Makkar and Yap 2018b), but nowadays, luxury brand managers need to fully comprehend not only what drives consumers to look for, purchase, and promote their brands, but also in what way those products will be consumed. While consumers from emerging luxury markets may be consuming such goods in a conspicuous manner (i.e., publicly and ostentatiously consuming luxury goods in order to signal their status to others), consumers from more traditional markets may choose a subtler way of consuming such goods that still allows them to differentiate from other social classes. The Economist stated that "being a conspicuous consumer is getting harder and harder" in the traditional markets, (The Economist 2005, p. 2). Yet, status still "plays a crucial role" in emerging ones, e.g., in Russia (Kaufmann et al. 2012, p. (14)222). The luxury marketing field has long been opulent in conspicuous consumption research (Makkar and Yap 2018a), but as The Economist anticipated in 2005 and AdAge (2010), the Huffington Post (2014), Harvard Business Review (2015), and The Frameworks (2015) confirmed, luxury is becoming inconspicuous, and not much is known about it (Makkar and Yap 2018a). However, scholars still determine that luxury consumption is, in certain markets (e.g., Russia, as previously mentioned), being driven conspicuously, in a parvenulike manner (Han et al. 2010). Clearly, there is a need for a quantitative investigation on the issue.

\section{Literature review}

\section{Luxury}

Academia has always had trouble defining luxury (Miller and Mills 2012), as its nature is constantly changing (Hudders et al. 2013).

Research has successfully depicted luxury's tangible attributes, it should portray high quality, uniqueness, rareness, and a sense of exclusivity (Kapferer 2014; Tian et al. 2001). All these traits should manifest themselves in products and services that, despite their high price, convey very low functional utility for the consumers, (i.e., have a low functional utility-to-price ratio) (Dubois 2001; Miller and Mills 2012; Nueno and Quelch 1998). Nonetheless, luxury is 
still a relative concept, with no generally accepted definition (Ko et al. 2017), as all the previously enunciated features of luxury are determined by customer perceptions of a luxury brand's ability to express them (Heine 2012; Ko et al. 2017; Wiedmann et al. 2007a).

Nevertheless, luxury should also bear a rich heritage (Dubois 2001), carry historical value (Cristini et al. 2017), provide pleasure as a central benefit, and promise access to a dream world (Hagtvedt and Patrick 2009). It does so through products and services that, through the incorporation of these traits, either via their design, manufacturing process, or associated marketing campaigns convey a sense of ethereal value, reflected in its high price (i.e., have a high intangible utility-to-price ratio (Dubois 2001; Miller and Mills 2012; Nueno and Quelch 1998). For a long time, such promise was associated with consumers' intention of status-signaling, as initially postulated by Veblen (1992). However, recent research suggests that differentiation can be declared inconspicuously, to render imitation more difficult (Makkar and Yap 2018a). The wide spread of luxury is now separating the traditional from new money consumers. Consequently, the former are changing their perceptions of luxury, giving rise to inconspicuousness, and proving luxury consumption to be more than a simple homogeneous concept (Kastanakis and Balabanis 2014), requiring an academic conceptualization that includes inconspicuousness.

Hence, we define luxury as a brand's ability to convey, on the one hand, an image of social prestige and elevation associated with a high-quality and exclusive product, commanding a high price and, on the other hand, uniqueness and singularity, inspiring a sense of distinction and inimitability, based on the promise of hedonic pleasure.

\section{Luxury brand management}

In the past, luxury was a "quieter" industry, with familyowned singular brands marketing products that represented their heritage (Kernstock et al. 2016). Nowadays, the industry is run by large conglomerates, which manage an extended luxury portfolio of businesses in several industries and distinct markets, ranging from apparel to wine (Kastanakis and Balabanis 2014). Their increasing worldwide presence (Kapferer and Florence 2018) results in a loss of the uniqueness element that was always associated with luxury. Currently, brands have to find "nifty" ways to compensate for such loss. Today's market is very heterogeneous (Kastanakis and Balabanis 2014), which leads to many possible understanding of what luxury means and, hence, to different forms of luxury consumption.

\section{Conspicuousness}

As previously mentioned, luxury caries historical value, revealing insights about the social norms and consumption patterns of a particular time, which could potentially help us to better understand its social and cultural foundations (Cristini et al. 2017). Such an idea is present in Veblen's (1992) theory, the basis of conspicuous consumption theory, in which he states that those with high income acquire and (publicly) use expensive goods for status-signaling purposes, thus enabling them to come closer to those who occupy a more prominent social hierarchical position. Even today, scholars expand further upon Veblen's notions (see, e.g., Bearden and Etzel 1982; Belk 1988; Dubois 2001; Piron 2000).

However, being a conspicuous consumer in traditional markets now seems to be more difficult than ever (Economist 2005). Research has revealed that the conspicuousness-brand relationship has become weaker over time, as a result of luxury's worldwide spread (Heine 2012; Hudders et al. 2013; Eckhardt et al. 2015).

Thus, the Theory of Consumption Values (TCV) was developed to explain why consumers make certain choices (buy or not to buy, or to use or not to use a specific product) (Sheth et al. 1991) which can be applied in the luxury industry. This theory may be used to predict consumer behavior, as well as to describe and explain it. The three fundamentals of this theory are (1) consumer choice is a function of multiple consumption values; (2) consumption values make differential contributions in any given choice situation; (3) the consumption values are independent. The theory identifies five consumption values influencing consumer choice behavior (functional value, conditional value, social value, emotional value, and epistemic value). In fact, values are seen as a stable variable for predicting attitudes and behaviors (Baek and Oh 2021).

As traditional consumers turn more and more away from conspicuousness, as a consequence of luxury value democratization, (Lewis and Moital 2016), the desire for inconspicuousness and a more subtle and inimitable luxury consumption rises (Shao et al. 2019b).

\section{Inconspicuousness}

Berger and Ward (2010) and Han et al. (2010) mentioned that, for certain consumers, wealth is not enough to achieve status. Instead, one would pursue a more discreet and sophisticated consumption that approached similar classes and causes dissociation from imitators. Eckhardt et al. (2015) 
have defined Inconspicuousness as the use of delicate and subtle signals, untraceable and unrecognizable to mainstream luxury consumers, but observable to those with the required level of knowledge. The rise of inconspicuous consumption emphasizes silent signals (Eckhardt et al. 2015). Thus, inconspicuous luxury is about acquiring and consuming expensive goods, without the objective of obtaining status or social prestige. Inconspicuous goods have low brand prominence and, thus, are only recognizable to insiders in the know (Berger and Ward 2010; Han et al. 2010), who have high levels of "cultural capital," which enables them to recognize such inconspicuous luxury consumption habits (Makkar and Yap 2018a 2018b). The inconspicuousness phenomenon has been gaining attention in academia (Wilson 2014; Wu and Borgerson 2017), but a further enriching of how such processes are triggered is necessary. We expand on such issues below.

\section{Luxury consumption antecedents}

\section{Cultural capital}

Academics seem to have achieved consensus on the idea that cultural capital plays a significant role in comprehending and forecasting consumer behavior (Berger and Ward 2010; Bernthal et al. 2005; Wei et al. 2019; Weinberger et al. 2017). Cultural capital is a concept that denotes one's social assets-(i.e., tastes, knowledge, mannerisms, skills, practices, and education level) - that determine one's level of social status and power (Bourdieu 1984; Makkar and Yap 2018b).

Bourdieu (1984) states that the consumption of art is, like that of other luxuries, predisposed and deliberate, fulfilling the function of social separation between classes. Such elite goods are described as requiring a significant level of Cultural Capital (CC), that is, a set of socially idiosyncratic and uncommon tastes, skills, practices, and acquaintance that determine one's projection of social status and power, as its accumulation is determined by one's level of education, social interactions, and upbringing (Bourdieu 1984; Holt 1998; Makkar and Yap 2018a).

Due to the democratization of luxury, elites in post-modern societies no longer feel the need to prove their social distinctiveness via conspicuous consumption (Hudders et al. 2013). Instead, they have to adjust their consumption practices, by consuming the same product categories in ways that are rather inaccessible to others (Holt 1998). Such unattainability is not demonstrated via economic capital, but rather via cultural capital, which translates into a deeper knowledge of the good's history, manufacturing process, details, and intricacies. The literature suggests that cultural capital allows the cultural elites to truly comprehend the value behind inconspicuous luxury brands (Bourdieu 1984;
Holt 1998; Makkar and Yap 2018a 2018b); its accumulation finely triggers an understanding of the delicate elements that characterize them.

Hence, the level of cultural capital will change one's consumption habits and interfere with their perceptions of luxury. For those with a high level of cultural capital, inconspicuous luxury is a distinctive consumption source and symbol of great taste and true exclusivity (Bernthal et al. 2005; Wei et al. 2019), while conspicuous luxury is vulgar and tasteless. Conversely, at a low level of cultural capital, conspicuous luxury consumption presents itself as the social differentiating factor (Berger and Ward 2010), while inconspicuous luxury will simply not even be understood as luxury, due to its subtleness which is unintelligible to such consumers.

Cultural capital and self-construal Wong and Ahuvia (1998) have differentiated between luxury consumers according to their propensity to focus on social connections. Some consumers place more emphasis on their Interdependent Self (INT) (Kastanakis and Balabanis 2014), which has been described by Markus and Kitayama as "seeing oneself as part of an encompassing social relationship and recognizing that one's behavior is determined, contingent on, and, to a large extent organized by what the actor perceives to be the thoughts, feelings, and actions of others in the relationship" (1991, p. 227). The application of such a definition to this study entails these consumers' comprehension of luxury still lacking complexity and further nurturing (i.e., their levels of cultural capital are low) (Makkar and Yap 2018a), leading them to a social understanding of luxury, focused on materialism and possessions. We argue that lower levels of cultural capital lead consumers towards improving their interdependent self-construal.

Conversely, other consumers focus on their Independent Self (IND) (Kastanakis and Balabanis 2014), described by Markus and Kitayama as "construing oneself as an individual whose behavior is organized and made meaningful primarily by reference to one's own internal repertoire of thoughts, feelings, and action, rather than by reference to the thoughts, feelings, and actions of others" (1991, p. 226). The application of such a definition to this study suggests that the mentioned consumers are extremely selective with their purchases, which in turn equips them with the right levels of knowledge to back up their purchase and consumption decisions (Makkar and Yap 2018a). Thus, we claim that higher levels of cultural capital lead consumers towards the improvement of their Independent Self-construal.

\section{Consumer need for uniqueness}

Consumer Need for Uniqueness (CNU) is "the trait of pursuing differentness relative to others through the acquisition, 
utilization, and disposition of consumer goods for the purpose of developing and enhancing one's self-image" (Tian et al. 2001, p.52). Considering the characteristics of luxury goods, researchers have devoted their attention to the tie between luxury consumption and CNU. Consumers with a high need for uniqueness manifest Avoidance of Similarity (AOS) behaviors, as they reduce their usage of certain luxury products if such products are no longer exclusive, and will rather seek goods that deviate from the norm (Kastanakis and Balabanis 2014; Tian et al. 2001). Hence, we argue not only that the product being inconspicuously consumed is different from the mainstream option, but also that it is not immediately understood and comprehended by the masses as a luxury product. We suggest that $\mathrm{CNU}$ will have a positive effect on inconspicuous luxury consumption.

Consumer need for uniqueness and cultural capital A higher need for uniqueness translates into an Unpopular Choice Counterconformity (UCC) (Tian et al. 2001), that is the search for products that deviate from the norm, potentially putting the consumer at risk of social disapproval. However, consumers with a high level of cultural capital tend to focus on the achievement of their own consumptionrelated goals. The high level of knowledge they evidence supports their consumption decisions, usually based on products that are more identity-relevant (Berger and Ward 2010). Their higher levels of Cultural Capital allow them to opt for luxury products that, due to their subtleness, provide personal satisfaction and, hence, shield them from embarrassment (Makkar and Yap 2018a). Hence, consumers with higher levels of cultural capital orient their luxury consumption decisions according to such needs. CNU, positively affected by cultural capital, mediates the relationship between the former and Inconspicuousness.

Consumer need for uniqueness and self-construal As explained above, consumers with higher levels of Cultural Capital place the relevant focus of luxury consumption on the achievement of their independent self-construal. Moreover, their level of knowledge supports their consumption decisions, based on self-relevant goods (Berger and Ward 2010). Higher levels of cultural capital enable the choice of subtler luxury products, thus providing differentiation from new money consumers (Husic and Cicic 2009), while at the same time avoiding embarrassment (Makkar and Yap 2018a). Consumers look for luxury products that distinguish them from other luxury consumers and enhance their independent self through dissociation from such consumers (Leibenstein 1950). We argue that building an independent self-construal will positively affect one's CNU.

\section{Susceptibility to normative influence}

Consumer susceptibility to Normative Influence (SNI) is "the need to identify or enhance one's image with significant others through the acquisition and use of products and brands, the willingness to conform to the expectations of others regarding purchase decisions" (Bearden et al. 1989, p. 474). Consumers with a high susceptibility to normative influence act according to what a certain reference group expects from them, so as to either avoid punishments or obtain rewards-a phenomenon Park and Lessig (1977) named Utilitarian Reference Group Influence (URGI). Such phenomena seem to be a fundamental basis of conspicuousness; in this case, luxury consumption is based on goods recognizable by the majority as a sound consumption choice (since it in fact played a major influencing role in their consumption to begin with). The influenced individual signals to the reference group an intention to belong (Kastanakis and Balabanis 2014). We suggest that susceptibility to normative influence will have a positive effect on conspicuous luxury consumption.

Susceptibility to normative influence and cultural capital Consumers with a low level of knowledge of the luxury market are concerned about the inferences that others may draw regarding their behavior, which will lead to higher Susceptibility to Normative Influence (Hoyer et al. 2018). In fact, consumers who are more susceptible to the influence of their peers tend to have a higher level of public self-consciousness, meaning that they try to create a favorable public image by consuming the types of luxury gods that they deem others will approve (Lewis and Moital 2016). Such consumption is a reflection of a low level of acquaintance with the luxury market, which translates into the purchase of conspicuous products (Makkar and Yap 2018a), as luxury is comprehended more as a social tool for imitating consumers, even in their desire to achieve higher status (Husic and Cicic 2009). Hence, low levels of Cultural Capital will shape one's luxury consumption decisions according to the reference group's norms. Susceptibility to Normative Influence, negatively affected by Cultural Capital, mediates the relationship between this and Conspicuousness.

Susceptibility to normative influence and self-construal According to Park and Lessig's (1997) ValueExpressive Reference Group Influence theory (VERGI), consumers with a greater Susceptibility to Normative Influence tend to act in certain ways that strengthen the reference group's impressions of them. It seems plausible to infer that new money luxury consumers (Husic and Cicic 2009) are 
motivated to comply with the opinions of those who they consider to be "in the know" (Makkar and Yap 2018a). Accordingly, luxury consumers who are more focused on their interdependent self-construal exhibit higher susceptibility to normative influence. Luxury consumption can, hence, be used as a tactic for associating with their aspirational reference groups (Kastanakis and Balabanis 2014). We propose that consumers with a greater focus on their interdependent self-construal exhibit higher susceptibility to normative influence.

The luxury market has been growing constantly since the 1990s (Wu et al. 2015) and the main revenue gatherers are still the traditional markets of Western Europe. However, the industry is being driven by the middle class in the emerging luxury markets, e.g., China, the UAE, and Russia, whose increasing purchasing power is increasing the current spending on luxury, leading to an erosion of the uniqueness that traditional consumers pursued according to uniqueness theory. This "democratization of luxury" is changing how traditional markets perceive luxury (Hudders et al. 2013). Therefore, being a conspicuous consumer is getting harder and harder in the traditional markets. Yet, status still plays a crucial role in emerging ones (Kaufmann et al. 2012). The luxury marketing field has long been replete with conspicuous consumption research (Makkar and Yap 2018a), but luxury is now going inconspicuous. Despite two previous research papers (Makkar and Yap 2018a 2018b) on the importance of cultural capital as a driver for changing from conspicuous to inconspicuous luxury consumption, the field remains wide open. However, the theory of conspicuous consumption is no longer the main reference of the luxury market.

\section{Conceptual framework and hypotheses}

In accordance with the literature review, this research proposes the theoretical model and the hypotheses bellow (see Fig. 1).

H1a Cultural capital has a positive effect on inconspicuousness.

H1b Cultural capital has a negative effect on conspicuousness.

H1c Cultural capital has a positive effect on independent self-construal.

H1d Cultural capital has a negative effect on interdependent self-construal.

H1e Cultural capital has a positive effect on consumer need for uniqueness.

H1f Cultural has a negative effect on susceptibility to normative influence.

H2a Independent self-construal has a positive effect on consumer need for uniqueness.

H2b Interdependent self-construal has a positive effect on susceptibility to normative influence.

H2c Independent self-construal has a positive effect on inconspicuousness.

Fig. 1 Theoretical model

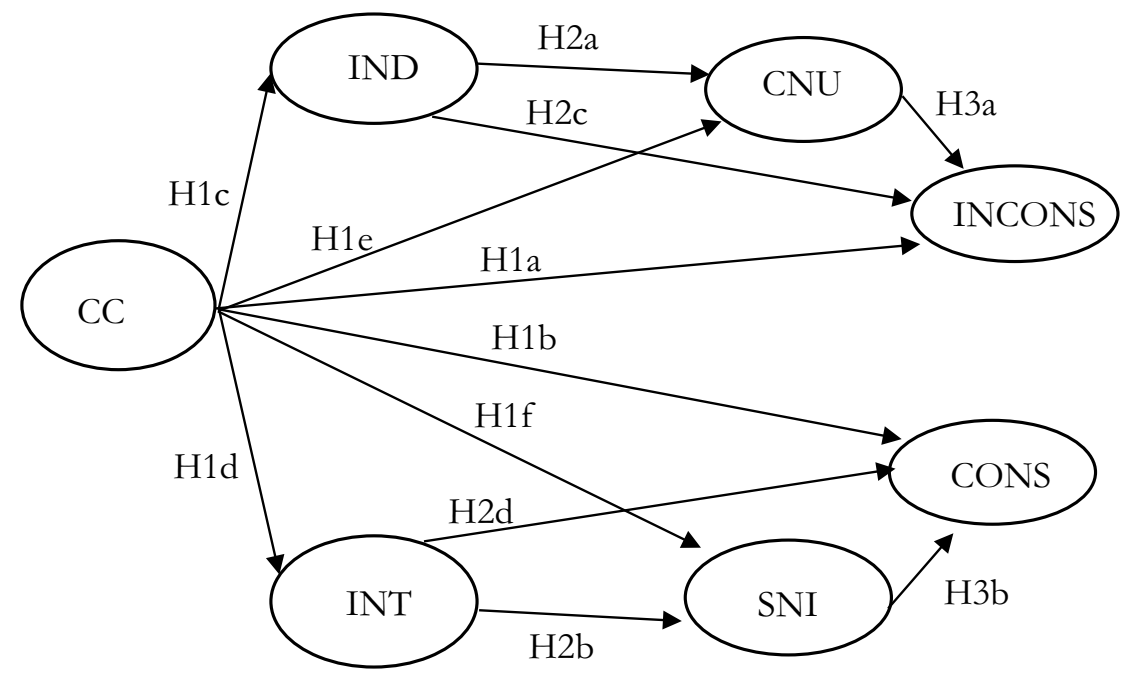

Notes: CC- Cultural Capital; IND- Individual Self-construal; INT- Interdependent Self-construal; CNUConsumer Needs for Uniqueness; SNI- Susceptibility to Normative Influence; INCONS- Inconspicuosness; CONS- Consciousness 
H2d Interdependent self-construal has a positive effect on conspicuousness.

H3a Consumer need for uniqueness has a positive effect on inconspicuousness.

H3b Susceptibility to normative influence has a positive effect on conspicuousness.

\section{Methodology}

This study employs a Partial Least Squares-based Structure Equation Modeling (PLS-SEM). Such modeling requires no distributional assumptions (Huang 2019), can be used for relatively small samples (Fornell and Bookstein 1982), and more effectively explores models underlying the theoretical structures of high complexity (Jöreskog and Wold 1982), since it is most often used to test and validate hypothesized relationships of exploratory models at a more theoretical level.

\section{Questionnaire design}

Specific questions regarding whether survey takers had previously bought luxury products and considered themselves luxury consumers were added at the beginning of the questionnaire.

Existing scales were selected to measure each of the constructs. The Inconspicuous consumption measurement scale, unlike the others, comprises items gathered from two studies, as a result, as far as the authors know, of the inexistence of a sound and empirically validated measurement scale for Inconspicuous Luxury Consumption. Finally, a set of demographic questions was added.

A 10-point Likert Scale, ranging from strongly disagree to strongly agree, was chosen, based on the exploration of the better and more accurate results that associated with such scales, when compared to a 5-point or 7-point scale, as argued by Awang et al. (2016).

Preemptive actions to counteract the negative effects of Common Method Bias were implemented (Conway and Lance 2010). To test the clarity of the formulation of the items, a pre-questionnaire was implemented with ten participants with different ethnicities, literary backgrounds, genders, and ages. The pertinence of the comments received indicated a need for adjustments, to mitigate all potential bias and second-hand interpretations. The questionnaire was, as a result, re-written in a much simpler form of English, to further mitigate possible misinterpretations. A second version of the questionnaire was later sent to these same 10 participants, who attested the validity of the final instrument.

The questionnaire administered was both via email and direct contact with potential respondents, requesting its completion and also sharing with family and friends, subject to the condition that it should only be answered by luxury consumers. The information collected was anonymous, and respondents were asked to authorize the collection and analysis of the data they provided, with the sole purpose of pursuing this investigation.

\section{Sample}

Data collection took place between April and May 2019. In total, 294 responses were obtained with one registering nothing but empty values in all items-we ended up with 293 exploitable replies. The vast majority of respondents claimed to have purchased luxury products before (79.5\%), although only a small percentage of respondents consider themselves generally to be luxury consumers $(26.6 \%)$. Nonetheless, no answers emerged as potential outliers.

Demographically, the data set was heterogenous in various respects, which we believe complies with the alreadymentioned level of heterogeneity in the current luxury landscape: $73 \%$ of respondents were female, while $26.3 \%$ were male $(0.7 \%$ preferred not to disclose their gender). The distribution of ages was as follows: $1.7 \%$ under 18 , $46.1 \%$ between 18 and $24,22.2 \%$ between 25 and 34, $10.9 \%$ between 35 and $44,10.2 \%$ between 45 and 74 and $8.9 \%$ above $55.36 .6 \%$ of respondents were students, and $43.2 \%$ employed full-time. The vast majority of the respondents were born in Albania (40.3\%), Portugal (33.8\%), and Italy $(12.3 \%)$.

\section{Results}

Three different studies were carried out. We first conducted a Confirmatory Factor Analysis, followed by a Partial LeastSquare Structure Equational Model Analysis. Finally, a Multi-Group Analysis was conducted. These studies used IBM SPSS Statistics 25 software and Smart PLS 3 software (Ringle et al. 2015).

\section{Reliability and validity}

Using SPSS 25 and SmartPLS 3, a factor analysis was conducted in order to test for reliability, which was initially measured via Cronbach's $\alpha$, which indicates how closely related a set of items are, within a specific group. The higher the value of $\alpha$, the more reliable the scale. According to Kline (2015), a Cronbach's $\alpha$ of around 0.90 is excellent. SmartPLS 3 suggests a threshold of 0.7. An analysis of each construct's pattern and covariance matrices suggested the elimination of items cc5, int1, sni6, cnu7, cons4, and cons5.

Through SmartPLS 3, Composite Reliability (CR) was analyzed as well. SmartPLS 3 suggests a threshold of 0.7 . 
The outer loadings of the model were calculated. Items loading less than 0.7 were eliminated, except for Consumer Need for Uniqueness: one loading of 0.69 was retained, maintaining a minimum of three items per construct to avoid estimation problems (Kline 2015). Values for both Cronbach's $\alpha$ and Composite Reliability are listed in Table 1 . We concluded that acceptable reliability had been achieved.

Subsequently, validity tests were conducted. The calculation of the Average Variance Extracted (AVE), using SmartPLS 3, allowed us to assess convergent validity (achieved when AVE is superior to 0.5) (Barclay et al. 1995). Convergent validity refers to the degree to which two different variables that have been theoretically hypothesized as correlated are, in fact so. AVE for all constructs exceeded 0.5 , thus confirming that all measurements exhibited satisfactory convergent validity. Next, the Heterotrait-Monotrait Ratio of Correlations (HTMT) was calculated, as suggested by Henseler et al. (2015) (Fig. 2). Discriminant validity (to verify if a reflective construct, in comparison with other constructs, has the strongest relationships with its own indicators) is achieved if HTMT values are lower than 0.9, according to the suggested SmartPLS threshold. For all constructs, HTMT was below the 0.9 (Fig. 3).

We thus concluded that satisfactory validity and reliability have been achieved.

\section{Findings}

Several path estimates for crucial theoretical relationships between constructs were statistically significant $(p<0.1)$. Thus, hypotheses, H1b, H1c, H1f, H3a, and H3b were supported $(p<0.1)$. All other hypotheses were not supported, despite H1d and H2a showing statistical significance.

This study demonstrated positive relationships both between Consumer Need for Uniqueness and Inconspicuous consumption (H3a) and between Susceptibility to Normative Influence and Conspicuous consumption (H3b); while some consume luxury as a way to conform to the expectation of their aspiration group, others satisfy an internal need to pursue something unusual by consuming luxury in an inconspicuous manner.

This research also confirmed the positive relationship between cultural capital and independent self-construal (H1c), as higher levels of cultural capital indeed translated into higher levels of luxury acquaintance, which results in a more personal-centric opinion around luxury.

The verified positive relationships between cultural capital and both susceptibility to normative influence (H1f) and conspicuousness (H1b) confirm that lower levels of cultural capital, which translates into an undeveloped comprehension of luxury, increase willingness to engage in a conspicuous luxury consumption activity (with the purpose of signaling the aspiration group), by mediating the normative influence exerted by others (H3b).

Fig. 2 Structural model

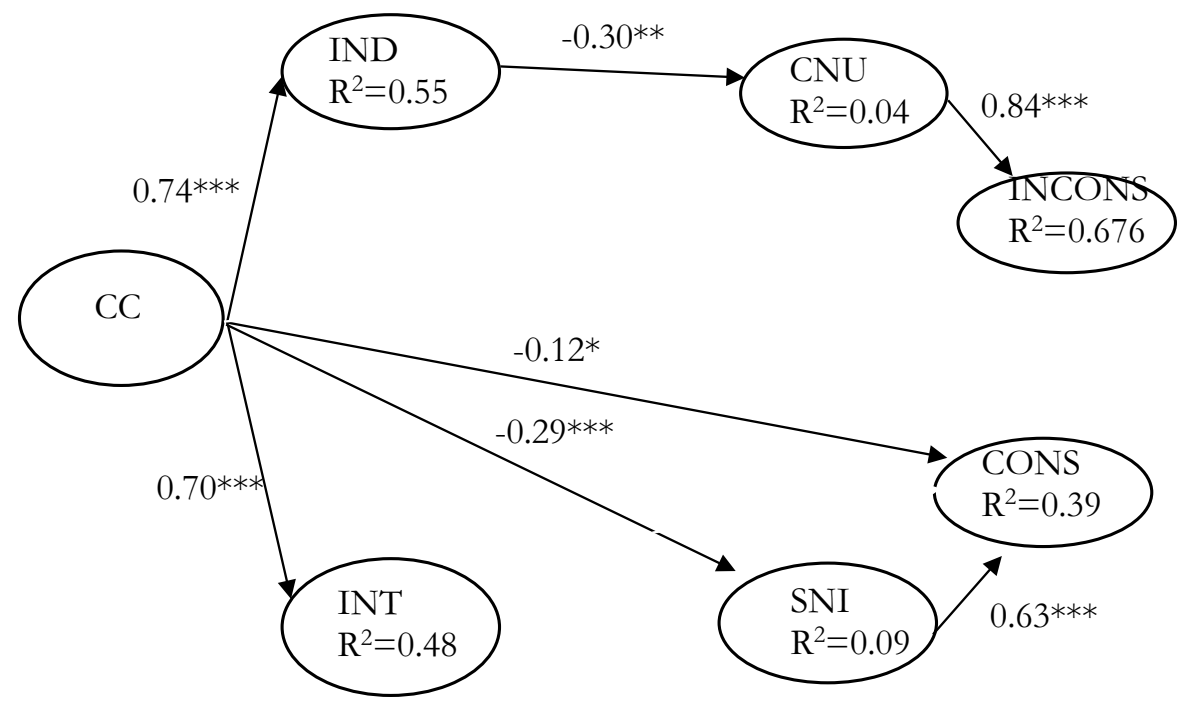

Notes: ${ }^{*} \mathrm{p}<0.1 ;{ }^{* *} \mathrm{p}<0.05 ;{ }^{* *} \mathrm{p}<0.01$; dashed lines: not significant; solid lines: significant

CC- Cultural Capital; IND- Individual Self-construal; INT- Interdependent Self-construal; CNUConsumer Needs for Uniqueness; SNI- Susceptibility to Normative Influence; INCONS-

Inconspicuosness; CONS- Consciousness 


\section{Heterotrait-Monotrait Ratio (HTMT)}

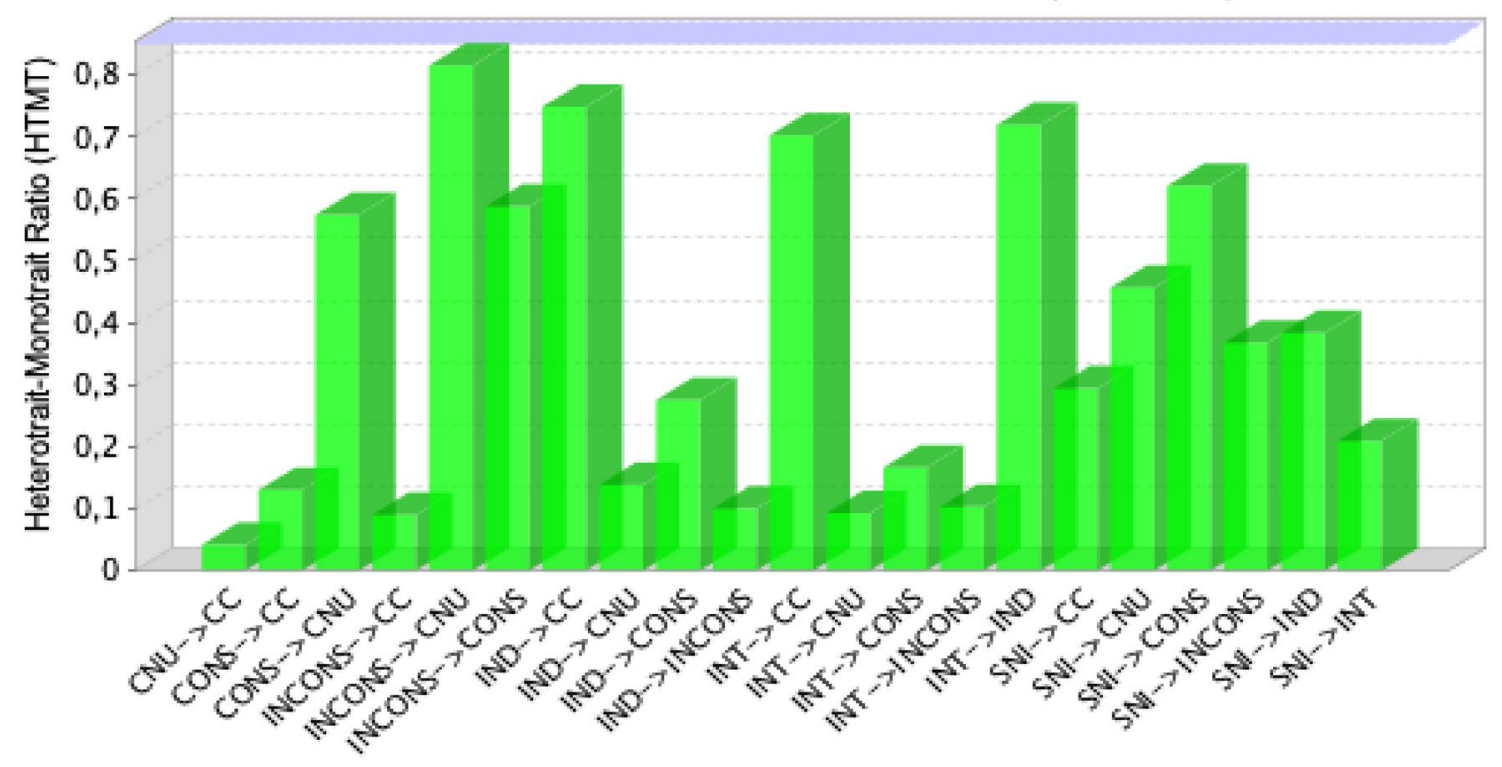

Fig. 3 HTMT Results, indicating that discriminant validity has been achieved

Table 1 Reliability and validity measurements

\begin{tabular}{llll}
\hline & Cronbach's $\alpha$ & CR & (AVE) \\
\hline CC & 0.76 & 0.76 & 0.52 \\
CNU & 0.76 & 0.76 & 0.51 \\
CONS & 0.90 & 0.90 & 0.76 \\
INCONS & 0.83 & 0.83 & 0.56 \\
IND & 0.89 & 0.89 & 0.62 \\
INT & 0.82 & 0.83 & 0.54 \\
SNI & 0.80 & 0.80 & 0.58 \\
\hline
\end{tabular}

In order to further investigate the indirect effects of cultural capital on conspicuous consumption through the mediator susceptibility to normative influence, both bias-corrected and percentile bootstrapping analysis were executed, using 1000 bootstrap samples to calculate $90 \%$ confidence intervals. The bootstrap results confirmed the existence of a positive and statistically significant mediating effect for susceptibility to normative influence between cultural capital and conspicuous consumption. Susceptibility to normative influence seems to result in consumers with a low level of CC being persuaded by other's choices and expectations when it comes to luxury consumption decisions. Nonetheless, we had initially hypothesized that interdependent self-construal would also mediate the relationship between cultural capital and conspicuousness. Even though $\mathrm{H} 2 \mathrm{~b}$ was not supported, further analysis of this relationship was conducted. Table2 shows the identified statistically significant specific indirect
Table 2 Total, Indirect, and Direct effects that $\mathrm{CC}$ has over Conspicuous consumption

\begin{tabular}{|c|c|c|c|c|c|}
\hline \multirow[t]{3}{*}{ Variables } & \multirow[t]{3}{*}{ Point estimate } & \multicolumn{4}{|c|}{ Bootstrapping } \\
\hline & & \multicolumn{2}{|c|}{$\begin{array}{l}\text { Bias-corrected } \\
90 \% \text { CI }\end{array}$} & \multicolumn{2}{|c|}{$\begin{array}{l}\text { Percentile } 90 \% \\
\text { CI }\end{array}$} \\
\hline & & Lower & Upper & Lower & Upper \\
\hline \multicolumn{6}{|l|}{ Total effects } \\
\hline $\begin{array}{l}\mathrm{CC} \rightarrow \mathrm{CONS} \\
\text { Indirect Effects }\end{array}$ & $-0.12^{*}$ & -0.24 & -0.01 & -0.23 & -0.01 \\
\hline $\begin{array}{l}\mathrm{CC} \rightarrow \mathrm{CONS} \\
\text { Direct effects }\end{array}$ & $-0.29 * *$ & -0.45 & -0.15 & -0.45 & -0.15 \\
\hline $\mathrm{CC} \rightarrow \mathrm{CONS}$ & $0.17 *$ & 0.01 & 0.31 & 0.02 & 0.32 \\
\hline
\end{tabular}

1000 bootstrap samples; two-tailed

${ }^{*} p<0.1 ; * * p<0.05$

effects. Indeed, interdependent self-construal does not mediate between the relationship in question-susceptibility to normative influence is the only mediator between cultural capital and conspicuous consumption (Table 3).

$\mathrm{H} 1 \mathrm{~d}$ and $\mathrm{H} 2 \mathrm{a}$ showed statistical significance. In contrast to the reviewed literature, our investigation has revealed evidence of a positive relationship between cultural capital and interdependent self-construal (H1d), and a negative relationship between Independent Self-construal and Consumer Need for Uniqueness ( $\mathrm{H} 2 \mathrm{a})$. Our analysis of these results follows below in Sect. 5, as they constitute an investigation opportunity for future research. 
Table 3 Specific Indirect Effects CC has over

Conspicuous consumption

\begin{tabular}{|c|c|c|c|c|c|}
\hline \multirow[t]{3}{*}{ Variable } & \multirow[t]{3}{*}{ Point estimate } & \multicolumn{4}{|c|}{ Bootstrapping } \\
\hline & & \multicolumn{2}{|c|}{$\begin{array}{l}\text { Bias-Corrected } 90 \% \\
\text { CI }\end{array}$} & \multicolumn{2}{|c|}{ Percentile $90 \%$ CI } \\
\hline & & Lower & Upper & Lower & Upper \\
\hline \multicolumn{6}{|c|}{ Specific Indirect Effects $\mathrm{CC} \rightarrow \mathrm{CONS}$} \\
\hline $\mathrm{CC} \rightarrow \mathrm{INT} \rightarrow \mathrm{SNI} \rightarrow \mathrm{CONS}$ & -0.01 (n.s.) & -0.10 & 0.11 & -0.11 & -0.10 \\
\hline $\mathrm{CC} \rightarrow \mathrm{SNI} \rightarrow \mathrm{CONS}$ & $-0.18^{*}$ & -0.35 & -0.04 & -0.34 & -0.04 \\
\hline $\mathrm{CC} \rightarrow \mathrm{INT} \rightarrow \mathrm{CONS}$ & 0.10 (n.s.) & -0.23 & 0.01 & -0.22 & 0.01 \\
\hline
\end{tabular}

1000 bootstrap samples

${ }^{*} p<0.1 ; * * p<0.05 ;$ n.s.: not significant

\section{Multi-group analysis}

Multi-group analysis was conducted in agreement with the nonparametric confidence set approach (Sarstedt et al. 2011). A PLS, 1000 bootstrap samples, two-tailed, bias-corrected 95\%-bootstrap CI was constructed for two different groups: Southern Europe (SE, NSE $=137)$ and Central and Eastern Europe $(\mathrm{CEE}, \mathrm{NCEE}=125)$ groups.

The SE group constituted survey answers from Spain, Greece, Italy, and Portugal, while the CEE group was composed of Albanian, Romanian, and Russian data. The nonparametric confidence set approach is that, if the parameter estimate for a path relationship of one group falls within the corresponding confidence interval of the other group, it is assumed that there are no significant differences between the group-specific path coefficients, for a specific significance level of confidence, which in this case is $95 \%$. The results are presented in Tables 4, 5, and 6 .

As can be seen, the correlations between cultural capital and consumer need for uniqueness, cultural capital, and conspicuousness and, finally, consumer need for uniqueness and inconspicuousness are different between SE and CEE groups.

However, the nonparametric confidence set approach works on the basis that significant differences found between the two group models are assumed to exist when the method's criteria are met. Thus, the standard SmartPLS3 MGA was conducted, in which we evaluated the p-value of the three correlations was found to be different between the two group models, for both groups individually and for the p-value of the difference between the effects of both groups (CEE - SE). The results can be found in Table 6. We concluded that the difference between the total effects of the correlations measured in both models is statistically significant. Furthermore, the correlations between cultural capital and both consumer need for uniqueness and conspicuous consumption are partially significant, while the correlation between consumer need for uniqueness and inconspicuousness is fully significant. One of the most significant differences between the two groups has to do with the impact of cultural capital on both consumer need for uniqueness and conspicuous luxury consumption. Specifically, this effect is nonsignificant in the CEE group and negative in the SE group. Such findings are of pivotal importance, since this study has been able to prove that there are indeed significant differences in the way culture impacts luxury consumption (Table 7).

\section{Conclusions}

\section{Theoretical implications}

Our study's main finding relates to the role consumer need for uniqueness plays as an antecedent of inconspicuousness. This is pertinent considering that scholars had mentioned the lack of related research (Hume and Mills 2013; Makkar and Yap 2018a 2018b), this discovery is of the utmost importance, as our finding corroborates similar conclusions from Shao et al.' (2019a). We make a strong conceptual contribution to the luxury consumption literature, by consolidating that, for certain consumer groups, a differentiating status can be affirmed without brand prominence, as a way to prevent imitation by others (Makkar and Yap 2018a 2018b). Uniqueness theory advocates that people try to manifest a desire for a different identity (Fromkin 1970). Hence, when a luxury consumer is pursuing distinctiveness from the herd (Kastanakis and Balabanis 2014), exhibiting a high need for uniqueness (Tian et al. 2001), there is a greater chance of consuming goods in a more delicate and subtle way, unidentifiable as luxury consumption to the mainstream luxury consumers. That is, the one will engage in inconspicuous consumption (Eckhardt et al. 2015).

The link between Cultural Capital and luxury consumption was also examined. On the one hand, no empirical evidence was found for the positive effect of cultural capital on inconspicuousness (Eckhardt et al. 2015; Makkar and Yap 2018a 2018b). Bourdieu's (1984) and Holt's (1998) theories, supported by Makkar and Yap (2018a 2018b), suggested that the accumulation of cultural capital enabled cultural 


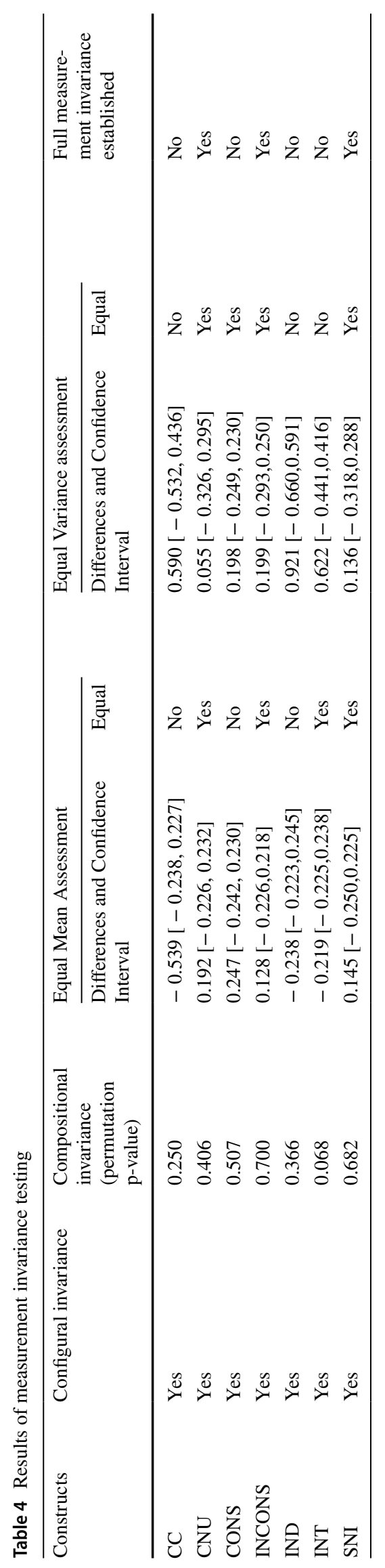


Table 5 MGA Output 1

\begin{tabular}{llll}
\hline Variables & Point estimate & \multicolumn{2}{l}{ Bootstrapping } \\
\cline { 3 - 4 } & & $\begin{array}{l}\text { Bias-corrected 95\% } \\
\text { CI (SE) }\end{array}$ \\
\cline { 3 - 4 } Total effects (CEE) & & Lower & Upper \\
\hline $\mathrm{CC} \rightarrow \mathrm{CNU}$ & 0.184 (n.s.) & -0.362 & -0.048 \\
$\mathrm{CC} \rightarrow \mathrm{CONS}$ & 0.027 (n.s.) & -0.424 & -0.03 \\
$\mathrm{CNU} \rightarrow>$ INCONS & $1.001 * * *$ & 0.606 & 0.92 \\
\hline
\end{tabular}

$\mathrm{N}_{\mathrm{CEE}}=125 ; \mathrm{N}_{\mathrm{SE}}=137 ; 1000$ bootstrap samples

$* p<0.05 ; * * * p<0.01 ;$ n.s.: not significant

Table 6 MGA Output 2

\begin{tabular}{llll}
\hline Variables & Point estimate & \multicolumn{2}{l}{ Bootstrapping } \\
\cline { 3 - 4 } & & $\begin{array}{l}\text { Bias-corrected } 95 \% \\
\text { CI (CEE) }\end{array}$ \\
\cline { 3 - 4 } Total effects (SE) & & Lower & Uppe \\
\hline $\mathrm{CC} \rightarrow \mathrm{CNU}$ & $-0.23 * * *$ & -0.029 & 0.397 \\
$\mathrm{CC} \rightarrow \mathrm{CONS}$ & $-0.25 * *$ & -0.154 & 0.231 \\
$\mathrm{CNU} \rightarrow \mathrm{INCONS}$ & $0.791 * * *$ & 0.823 & 1.190 \\
\hline $\mathrm{N}_{\mathrm{CEE}}=125 ; \mathrm{N}_{\mathrm{SE}}=137 ; 1000$ bootstrap samples & \\
$* * p<0.05 ; * * * p<0.01 ;$ n.s.: not significant &
\end{tabular}

Table 7 MGA difference between CEE and SE groups

\begin{tabular}{llll}
\hline Variables & $\begin{array}{l}\text { Total effects } \\
\text { original (CEE) }\end{array}$ & $\begin{array}{l}\text { Total effects } \\
\text { original (SE) }\end{array}$ & $\begin{array}{l}\text { Total effects- } \\
\text { diff (ICEE- } \\
\text { SEl) }\end{array}$ \\
\hline $\mathrm{CC} \rightarrow \mathrm{CNU}$ & 0.139 (n.s.) & $-0.186 * *$ & $0.326 * * *$ \\
$\mathrm{CC} \rightarrow \mathrm{CONS}$ & 0.021 (n.s.) & $-0.222 * *$ & $0.244^{* *}$ \\
$\mathrm{CNU} \rightarrow \mathrm{INCONS}$ & $0.759 * *$ & $0.622 * * *$ & $0.137 * *$ \\
\hline
\end{tabular}

$\mathrm{N}_{\mathrm{CEE}}=125 ; \mathrm{N}_{\mathrm{SE}}=137 ; 1000$ bootstrap samples; two-tailed

$* p<0.05 ; * * * p<0.01 ;$ n.s.: not significant

elites to comprehend luxury in a unique manner. However, our research revealed that the relationship between cultural capital and inconspicuousness is statistically insignificant.

Alternatively, this research demonstrated the negative influence cultural capital has on conspicuousness, both directly and indirectly, as it negatively affects one's susceptibility to normative influence, which in turn positively contributes to conspicuous luxury consumption. In particular, the less cultural capital acquired, the less luxury understanding one will have, which will translate into consumption habits that easily cause an association with higher status groups (Han et al. 2010). Hence, there will be greater conformity to the rules that allow membership to a certain group (Kastanakis and Balabanis 2014).

This paper also sheds light on the differences between how CEE and SE consumers consume luxury. In particular, SE consumers reduce conspicuous consumption as cultural capital accumulates. Our discoveries seem to be aligned with research stating that cultural differences alter consumer behavior, while changing perceptions of luxury (Shaw and Clarke 1998; Miller 2005; Wiedmann et al. 2007b; Godey et al. 2013). For example, Italian luxury consumers immediately use the word "exclusive" to describe luxury (Godey et al. 2013). Since luxury is an élite privilege that only belongs to a certain few, and belonging is not only an important element of luxury but also strongly associated with connoisseurship (Cervellon and Shammas 2013; Husic and Cicic 2009), the more identity investments a southern European consumer makes in luxury, the more cultural capital is acquired (Wei et al. 2019) and the less conspicuous the consumption will be, as conspicuous products are more not only accessible but also consumed by the "new money" (Husic and Cicic 2009).

Conversely, CEE exhibited a more accentuated effect of consumer need for uniqueness on inconspicuousness, with cultural capital exerting no significant effect over conspicuousness and consumer need for uniqueness. Accordingly, and considering that consumer need for uniqueness positively predicts Inconspicuousness, we could potentially explain this using Tian et al.'s (2001) Creative Choice Counterconformity (CCC) phenomenon. That is, despite choosing products that enhance their uniqueness, consumers will still select goods that are considered good choices by others. Hence, a higher consumer need for uniqueness would translate into the purchase of goods that, having low brand prominence, could still be recognizable by a few insiders (Berger and Ward 2010; Han et al. 2010).

\section{Practical implications}

Our discoveries enable new ways and strategies to mould costumer experience, which is indeed an essential pillar of luxury consumption.

Inconspicuous brands should design pull-type marketing campaigns that enhance consumer need for uniqueness, based on uniqueness-signaling communication which demonstrates individuality and distinctiveness, since consumers who acquire a luxury brand for the communication of central beliefs and values respond positively to more valueexpressive advertising (Shao et al. 2019b). Conversely, managers targeting conspicuous costumers may want to design push-type campaigns that entice group shopping and convey a public display of status. From this set of ideas follows the need to carefully choose which touchpoints consumers 
should use to engage with the brand. Retail managers must develop training schemes to aid sales associated with recognizing prompts indicating either inconspicuous or conspicuousness, and then to tailor the costumer experience in store. Discrete brands should invest in the uniqueness of consumption experiences and inimitability of product quality and design as the two indispensable elements of the instore purchasing experience (e.g., sales associates trained to be more sensitive to inconspicuousness). Product customization should also be available. Contrarywise, brands targeting conspicuous consumers should encourage group purchasing experiences.

In-store assortment can also be altered: inconspicuous consumers should have access to a deeper, wider, and more exclusive assortment, to satisfy their higher consumer need for uniqueness. Conversely, conspicuous consumers may want access to an assortment that showcases the most frequently sold variations of each product.

Finally, our research suggests that new types of consumption-related data can be recorded. Inconspicuous and conspicuous purchasing information allows managers to analyze and match the demand of those different customer segments.

\section{Limitations and suggestions for future research}

This study's results are constrained by the lack of appropriate Cultural Capital and Inconspicuous luxury consumption measurement scales, which is, in itself, a consequence of the lack of investigation in the field. Further research could thus delve into their development.

Future academics should venture into the relationship between Inconspicuousness and Consumer Need for Uniqueness, by investigating, for example, the possible effects of the different consumer need for uniqueness dimensions proposed by Tian et al. (2001) on inconspicuousness.

Additionally, further investigation on this study's hypotheses that have not found empirical support but were still statistically significant, should be conducted. Our research revealed that the accumulation of Cultural Capital positively affects Interdependent Self-construal. According to Husic and Cicic's (2009), the purchase of a brand signals the desire to be associated with the group which frequently uses it and that " "new money', (...) imitate the first group [the 'aristocracy'] in everything, including their aspiration to distinguish themselves from others" (Husic and Cicic 2009, p. 243). Moreover, our results revealed statistical significance of the negative effect of independent self-construal over consumer need for uniqueness. Curiously, need for uniqueness theory suggests that consumers will still try to preserve a certain level of resemblance to others (Snyder and Fromkin 1980), while independent self-construal theory argues that behavior is arranged according to one's own self-references, ultimately becoming meaningful as a result of such organization (Markus and Kitayama 1991). This indicates that construing an IND leaves no room for any level of similarity to others. More research on these potential theoretical implications should be conducted.

Finally, further investigation into the effect of creative choice counterconformity on Inconspicuousness in Central and Eastern European countries could contribute the further understanding of how Consumer Need for Uniqueness affects Inconspicuousness.

\section{Appendix 1 Constructs and Measurement Items}

\begin{tabular}{|c|c|c|c|}
\hline \multirow[t]{15}{*}{$\begin{array}{l}\text { Cultural } \\
\text { Capital }\end{array}$} & $\mathrm{cc} 1$ & $\begin{array}{l}\text { I buy lots of books, } \\
\text { read them, and keep } \\
\text { them in my library }\end{array}$ & $\begin{array}{c}\text { (Khodadady and } \\
\text { Natanzi 2012) }\end{array}$ \\
\hline & $\mathrm{cc} 2$ & $\begin{array}{l}\text { I attend handy-craft } \\
\text { galleries }\end{array}$ & \\
\hline & $\mathrm{cc} 3$ & $\begin{array}{l}\text { I have grown up in a } \\
\text { civilized family }\end{array}$ & \\
\hline & $\mathrm{cc} 4$ & $\begin{array}{l}\text { I am a civilized } \\
\text { person }\end{array}$ & \\
\hline & $\operatorname{cc} 5$ & $\begin{array}{l}\text { I have a personal } \\
\text { library in my room, } \\
\text { and I like to add } \\
\text { books to it }\end{array}$ & \\
\hline & cc6 & $\begin{array}{l}\text { I visit museums/his- } \\
\text { torical places }\end{array}$ & \\
\hline & $\mathrm{cc} 7$ & $\begin{array}{l}\text { I read fashion maga- } \\
\text { zines }\end{array}$ & \\
\hline & $\operatorname{cc} 8$ & $\begin{array}{l}\text { I buy newspapers } \\
\text { regularly }\end{array}$ & \\
\hline & cc9 & $\begin{array}{l}\text { I would like to } \\
\text { continue/have con- } \\
\text { tinued my education } \\
\text { to a higher level }\end{array}$ & \\
\hline & cc10 & $\begin{array}{l}\text { My parents read in } \\
\text { their leisure time }\end{array}$ & \\
\hline & cc11 & $\begin{array}{l}\text { I have fluency of } \\
\text { speech and people } \\
\text { understand me } \\
\text { easily }\end{array}$ & \\
\hline & cc12 & $\begin{array}{l}\text { I visit art galleries/ } \\
\text { fashion shows }\end{array}$ & \\
\hline & cc13 & $\begin{array}{l}\text { I visit news and } \\
\text { political websites }\end{array}$ & \\
\hline & cc14 & $\begin{array}{l}\text { I watch documen- } \\
\text { taries }\end{array}$ & \\
\hline & cc15 & $\begin{array}{l}\text { My parents can/could } \\
\text { communicate in } \\
\text { English }\end{array}$ & \\
\hline
\end{tabular}




\begin{tabular}{|c|c|c|c|c|c|c|c|}
\hline & cc16 & $\begin{array}{l}\text { I am interested in } \\
\text { literature and poetry } \\
\text { and have literal } \\
\text { studies }\end{array}$ & & & sni6 & $\begin{array}{l}\text { It is important to } \\
\text { me to have a lot of } \\
\text { friends with whom } \\
\text { I can do things }\end{array}$ & \\
\hline & $\operatorname{cc} 17$ & I attend art courses & & & sni7 & When I buy the same & \\
\hline \multirow[t]{7}{*}{$\begin{array}{l}\text { Independent } \\
\text { Self-Construal }\end{array}$} & ind1 & $\begin{array}{l}\text { My personal identity } \\
\text { is important to }\end{array}$ & & & & $\begin{array}{l}\text { things my friends } \\
\text { buy, I feel closer to } \\
\text { them }\end{array}$ & \\
\hline & ind2 & $\begin{array}{l}\text { myself } \\
\text { reliant rather than } \\
\text { depending on others }\end{array}$ & $\begin{array}{l}\text { (W. Gudykunst } \\
\text { et al. 1994) }\end{array}$ & $\begin{array}{l}\text { Consumer } \\
\text { Need for } \\
\text { Uniqueness }\end{array}$ & cnu1 & $\begin{array}{l}\text { When shopping/ } \\
\text { dressing, I have } \\
\text { sometimes dared to } \\
\text { be different in ways }\end{array}$ & (Tian et al. 2001) \\
\hline & ind3 & $\begin{array}{l}\text { I take responsibility } \\
\text { for my own actions }\end{array}$ & & & & $\begin{array}{l}\text { that others are likely } \\
\text { to disapprove }\end{array}$ & \\
\hline & ind4 & $\begin{array}{l}\text { It is important for me } \\
\text { to act as an inde- } \\
\text { pendent person }\end{array}$ & & & cnu2 & $\begin{array}{l}\text { I avoid product/ } \\
\text { brands that have } \\
\text { already been }\end{array}$ & \\
\hline & ind5 & $\begin{array}{l}\text { I should decide my } \\
\text { future on my own }\end{array}$ & & & & $\begin{array}{l}\text { accepted and } \\
\text { purchased by the }\end{array}$ & \\
\hline & ind6 & I enjoy being unique & & & & average consumer & \\
\hline & & $\begin{array}{l}\text { and different from } \\
\text { others }\end{array}$ & & & cnu3 & $\begin{array}{l}\text { I have often gone } \\
\text { against the under- }\end{array}$ & \\
\hline \multirow[t]{7}{*}{$\begin{array}{l}\text { Interdependent } \\
\text { Self-Construal }\end{array}$} & int1 & $\begin{array}{l}\text { It is important to con- } \\
\text { sult close friends } \\
\text { and get their ideas } \\
\text { before making a } \\
\text { decision }\end{array}$ & & & & $\begin{array}{l}\text { stood rules of my } \\
\text { social group regard- } \\
\text { ing when and how } \\
\text { certain products are } \\
\text { properly used }\end{array}$ & \\
\hline & int2 & $\begin{array}{l}\text { I will sacrifice my } \\
\text { self-interest in ben- } \\
\text { efit of the group }\end{array}$ & & & cnu4 & $\begin{array}{l}\text { I give up wearing } \\
\text { fashions I have } \\
\text { purchased once they }\end{array}$ & \\
\hline & Int3 & $\begin{array}{l}\text { I respect decisions } \\
\text { made by my group }\end{array}$ & & & & $\begin{array}{l}\text { among the general } \\
\text { public }\end{array}$ & \\
\hline & Int4 & $\begin{array}{l}\text { I stick with my group } \\
\text { even through dif- } \\
\text { ficulties }\end{array}$ & & & cnu5 & $\begin{array}{l}\text { I have often violated } \\
\text { the understood rules } \\
\text { of my social group }\end{array}$ & \\
\hline & Int5 & $\begin{array}{l}\text { I maintain harmony } \\
\text { in the groups }\end{array}$ & & & & $\begin{array}{l}\text { regarding what to } \\
\text { buy or own }\end{array}$ & \\
\hline & & $\begin{array}{l}\text { of which I am a } \\
\text { member }\end{array}$ & & & cnu6 & $\begin{array}{l}\text { The more common- } \\
\text { place a product or }\end{array}$ & \\
\hline & Int6 & $\begin{array}{l}\text { I comply with the } \\
\text { majority's wishes in } \\
\text { groups of which I } \\
\text { am a member }\end{array}$ & & & & $\begin{array}{l}\text { brand is among the } \\
\text { general population, } \\
\text { the less interested I } \\
\text { am in buying it }\end{array}$ & \\
\hline \multirow[t]{6}{*}{$\begin{array}{l}\text { Susceptibility } \\
\text { to Normative } \\
\text { Influence }\end{array}$} & snil & $\begin{array}{l}\text { When I shop for a } \\
\text { brand, it is impor- } \\
\text { tant to me that my } \\
\text { friends like it }\end{array}$ & (Batra et al. 2001) & & cnu7 & $\begin{array}{l}\text { Concern for being out } \\
\text { of place does not } \\
\text { prevent me from } \\
\text { wearing what I want }\end{array}$ & \\
\hline & sni2 & When I shop for a & & & & to wear & \\
\hline & & $\begin{array}{l}\text { brand, it is impor- } \\
\text { tant to me that my } \\
\text { friends have it }\end{array}$ & & \multirow[t]{4}{*}{$\begin{array}{l}\text { Conspicuous } \\
\text { Luxury Con- } \\
\text { sumption }\end{array}$} & cons 1 & $\begin{array}{l}\text { I purchase branded } \\
\text { products/services } \\
\text { because they make }\end{array}$ & $\begin{array}{l}\text { (Souiden et al. } \\
\text { 2011) }\end{array}$ \\
\hline & sni3 & I like buying the same & & & & me gain respect & \\
\hline & & $\begin{array}{l}\text { products/brand that } \\
\text { my friends do }\end{array}$ & & & cons 2 & $\begin{array}{l}\text { I purchase branded } \\
\text { products/services }\end{array}$ & \\
\hline & sni4 & $\begin{array}{l}\text { My friends and I tend } \\
\text { to buy the same } \\
\text { brands }\end{array}$ & & & & $\begin{array}{l}\text { because they } \\
\text { enhance my popu- } \\
\text { larity }\end{array}$ & \\
\hline
\end{tabular}

sni5 I buy brands which will make me look good in front of my friends 


\begin{tabular}{|c|c|c|c|}
\hline & cons 3 & $\begin{array}{l}\text { I purchase branded } \\
\text { products/services } \\
\text { because they make } \\
\text { me noticed by } \\
\text { others }\end{array}$ & \\
\hline & cons 4 & $\begin{array}{l}\text { I purchase branded } \\
\text { products/services in } \\
\text { order to show who } \\
\text { I am }\end{array}$ & \\
\hline & cons 5 & I like luxury & \\
\hline \multirow[t]{5}{*}{$\begin{array}{l}\text { Inconspicuous } \\
\text { Luxury Con- } \\
\text { sumption }\end{array}$} & incons 1 & $\begin{array}{l}\text { When purchas- } \\
\text { ing clothing and } \\
\text { apparel, it is } \\
\text { important for me to } \\
\text { choose items that } \\
\text { differentiate me } \\
\text { from other consum- } \\
\text { ers }\end{array}$ & $\begin{array}{l}\text { (Berger and Ward } \\
\text { 2010; Dogan } \\
\text { et al. 2018) }\end{array}$ \\
\hline & incons2 & $\begin{array}{l}\text { It is important for me } \\
\text { to avoid things that } \\
\text { other consumers } \\
\text { would buy }\end{array}$ & \\
\hline & incons 3 & $\begin{array}{l}\text { I do not enjoy buying } \\
\text { a product/service } \\
\text { that can be bought } \\
\text { by the vast majority } \\
\text { of society }\end{array}$ & \\
\hline & incons4 & $\begin{array}{l}\text { It bothers me when } \\
\text { many of the people } \\
\text { around me have a } \\
\text { product that I have }\end{array}$ & \\
\hline & incons5 & $\begin{array}{l}\text { I would like to feel } \\
\text { that I belong to an } \\
\text { exclusive minor- } \\
\text { ity through the } \\
\text { products/services I } \\
\text { purchase }\end{array}$ & \\
\hline
\end{tabular}

\section{Appendix 2 Geographical distribution of answers}

\begin{tabular}{|c|c|c|c|c|c|c|c|c|c|}
\hline Albania & Brazil & China & $\begin{array}{l}\text { Den- } \\
\text { mark }\end{array}$ & $\begin{array}{l}\text { Deut } \\
\text { schland }\end{array}$ & Spain & Finland & Greece & India & Italy \\
\hline $40.3 \%$ & $0.7 \%$ & $0.3 \%$ & $0.3 \%$ & $0.3 \%$ & $0.3 \%$ & $0.3 \%$ & $0.3 \%$ & $0.3 \%$ & $12,3 \%$ \\
\hline Mexico & Mixed & $\begin{array}{l}\text { No } \\
\text { Answer }\end{array}$ & Nigeria & Portugal & $\begin{array}{c}\text { Roma- } \\
\text { nia }\end{array}$ & Russia & $\begin{array}{c}\text { South } \\
\text { Africa }\end{array}$ & $\begin{array}{l}\text { South } \\
\text { Korea }\end{array}$ & $\begin{array}{l}\text { Thai- } \\
\text { land }\end{array}$ \\
\hline $0.3 \%$ & $0.7 \%$ & $3,1 \%$ & $0.3 \%$ & $33,8 \%$ & $1,0 \%$ & $1,4 \%$ & $1,7 \%$ & $0.3 \%$ & $1,7 \%$ \\
\hline
\end{tabular}

Acknowledgement This research has been financed by Portuguese public funds through FCT - Fundação para a Ciência e a Tecnologia, I.P., in the framework of the project UID/ECO/04105/2020.

Funding Funding was provided by Fundação para a Ciência e a Tecnologia, I.P (UID/ECO/04105/2020).

\section{Declarations}

Conflict of interest None.

\section{References}

Awang, Z., A. Afthanorhan, and M. Mamat. 2016. The Likert scale analysis using parametric based Structural Equation Modeling (SEM). Computational Methods in Social Sciences 4 (1): 13.

Baek, E., and G.E. Oh. 2021. Diverse values of fashion rental service and contamination concern of consumers. Journal of Business Research 123: 165-175. https://doi.org/10.1016/j.jbusres.2020. 09.061.

Bain \& Company. 2017. Luxury Goods Worldwide Market Study, FallWinter 2017 The New Luxury Consumer: Why Responding to the Millennial Mindset Will Be Key. https://www.bain.com/insights/ luxury-goods-worldwide-market-study-fall-winter-2017/

Barclay, D., R. Thompson, and C. Higgins. 1995. The Partial Least Squares (PLS) Approach to Causal Modeling: Personal Computer Use as an Illustration (Vol. 2).

Batra, R., P.M. Homer, and L.R. Kahle. 2001. Values, susceptibility to normative influence, and attribute importance weights: A nomological analysis. Journal of Consumer Psychology 11 (2): $115-128$.

Bearden, W., R. Netemeyer, and J.E. Teel. 1989. Measurement of Consumer Susceptibility to Interpersonal Influence (Vol. 15).

Bearden, W.O., and M.J. Etzel. 1982. Reference group influence on product and brand purchase decisions. Journal of Consumer Research 9 (2): 183-194.

Belk, R.W. 1988. Possessions and the extended self. Journal of Consumer Research 15 (2): 139-168.

Berger, J., and M. Ward. 2010. Subtle signals of inconspicuous consumption. Journal of Consumer Research 37 (4): 555-569.

Bernthal, M.J., D. Crockett, and R.L. Rose. 2005. Credit cards as lifestyle facilitators. Journal of Consumer Research 32 (1): 130-145.

Bourdieu, P. 1984. A social critique of the judgement of taste. Traducido del francés por R. Nice. Londres, Routledge.

Cervellon, M.-C., and L. Shammas. 2013. The Value of Sustainable Luxury in Mature Markets. Journal of Corporate Citizenship 52: 1.

Conway, J.M., and C.E. Lance. 2010. What reviewers should expect from authors regarding common method bias in organizational research. Journal of Business and Psychology 25 (3): 325-334.

Crain, R. 2010. Inconspicuous Consumption Will Motivate Consumers in Next Decade - Marketers Must Find New Ways to Appeal to the Financially Cautious if We Want to Speed Recovery. Retrieved from AdAge website: https://adage.com/article/rance-crain/incon spicuous-consumption-motivate-consumers-2010s/141240/

Cristini, H., H. Kauppinen-Räisänen, M. Barthod-Prothade, and A. Woodside. 2017. Toward a general theory of luxury: Advancing from workbench definitions and theoretical transformations. Journal of Business Research 70: 101-107.

Delloite. 2017. Global Powers of Luxury Goods 2017 - The new luxury consumer. Retrieved from https://www2.deloitte.com/content/ dam/Deloitte/global/Documents/consumer-industrial-products/ gx-cip-global-powers-luxury-2017.pdf

Delloite. 2018. Global Powers of Luxury Goods 2018 - Shaping the future of the luxury industry. Retrieved from https://www2.deloi tte.com/content/dam/Deloitte/global/Documents/Consumer-Busin ess/cb-global-powers-luxury-goods-2018.pdf 
Dogan, V., B.Y. Ozkara, and M. Dogan 2018. Luxury consumption tendency: conceptualization, scale development and validation. Current Psychology, 1-19.

Dubois, B. 2001. Consumer rapport to luxury: Analyzing complex and ambivalent attitudes.

Eckhardt, G.M., R.W. Belk, and J.A.J. Wilson. 2015. The rise of inconspicuous consumption. Journal of Marketing Management 31 (7-8): 807-826. https://doi.org/10.1080/0267257X.2014.989890.

Economist, T. 2005. Inconspicuous consumption - Now that luxury has gone mass market, how are the super-rich to flaunt their wealth? Retrieved from The Economist website: https://www.economist. com/special-report/2005/12/20/inconspicuous-consumption

Fornell, C., and F.L. Bookstein. 1982. Two structural equation models: LISREL and PLS applied to consumer exit-voice theory. Journal of Marketing Research 19 (4): 440-452.

Fromkin, H.L. 1970. Effects of experimentally aroused feelings of undistinctiveness upon valuation of scarce and novel experiences. Journal of Personality and Social Psychology 16 (3): 521-529. https://doi.org/10.1037/h0030059.

Godey, B., D. Pederzoli, G. Aiello, R. Donvito, K.-P. Wiedmann, and N. Hennigs. 2013. A cross-cultural exploratory content analysis of the perception of luxury from six countries. Journal of Product and Brand Management 22 (3): 229-237.

Gudykunst, W., Y. Matsumoto, S. Ting-Toomey, T., Nishida, and H. Karimi. 1994. Measuring self construals across cultures: A derived etic analysis. Paper presented at the International Communication Association Convention in Sydney, Australia.

Hagtvedt, H., and M. Patrick, V. 2009. The broad embrace of luxury: Hedonic potential as a driver of brand extendibility (Vol. 19).

Han, Y.J., J.C. Nunes, and X. Drèze. 2010. Signaling Status with Luxury Goods: The Role of Brand Prominence. Journal of Marketing 74 (4): 15-30. https://doi.org/10.1509/jmkg.74.4.15.

Heine, K. 2012. The Concept of Luxury Brands. Luxury Brand Management $1: 2$

Henseler, J., C.M. Ringle, and M. Sarstedt. 2015. A new criterion for assessing discriminant validity in variance-based structural equation modeling. Journal of the Academy of Marketing Science 43 (1): 115-135.

Holt, D.B. 1998. Does Cultural Capital Structure American Consumption? Journal of Consumer Research 25 (1): 1-25. https://doi.org/ $10.1086 / 209523$.

Hoyer, W.D., D.J. MacInnis, and R. Pieters. 2018. Consumer behavior, 7th ed. Boston: Cengage learning.

Huang, T.-L. 2019. Psychological mechanisms of brand love and information technology identity in virtual retail environments. Journal of Retailing and Consumer Services 47: 251-264. https://doi.org/ 10.1016/j.jretconser.2018.11.016.

Hudders, L., M. Pandelaere, and P. Vyncke. 2013. Consumer Meaning Making: The Meaning of Luxury Brands in a Democratised Luxury World. International Journal of Market Research 55 (3): 391-412. https://doi.org/10.2501/IJMR-2013-036.

Hume, M., and M. Mills. 2013. Uncovering Victoria's Secret: Exploring women's luxury perceptions of intimate apparel and purchasing behaviour. Journal of Fashion Marketing and Management 17 (4): 460-485. https://doi.org/10.1108/JFMM-03-2013-0020.

Husic, M., and M. Cicic. 2009. Luxury consumption factors. Journal of Fashion Marketing and Management: An International Journal 13 (2): 231-245.

Job, A. 2015. Inconspicuous luxury? It's just human nature. Retrieved from https://www.theframeworks.com/blog/2015/10/06/incon spicuous-luxury-it-s-just-human-nature

Jöreskog, K.G., and H. Wold. 1982. The ML and PLS Techniques for Modeling with Latent Variables: Historical and Comparative Aspects. Systems under Indirect Observation, Part I, Herman OA Wold and Karl G. Jöreskog, eds., Amsterdam: North-Holland, pp. 263-270.
Kapferer, J.-N. 2014. The future of luxury: Challenges and opportunities (Vol. 21).

Kapferer, J.N.M., and P. Valette-Florence. 2018. The impact of increased brand penetration on luxury desirability: A dual effect. Journal of Brand Management 25 (5): 424-435. https://doi.org/ 10.1057/s41262-018-0091-7.

Kastanakis, M.N., and G. Balabanis. 2014. Explaining variation in conspicuous luxury consumption: An individual differences' perspective. Journal of Business Research 67 (10): 2147-2154. https:// doi.org/10.1016/j.jbusres.2014.04.024.

Kaufmann, H., D. Vrontis, and Y. Manakova. 2012. Perception of luxury: Idiosyncratic Russian consumer culture and identity (Vol. 2).

Kernstock, J., T. Brexendorf, and S. Powell. 2016. Introduction: Luxury Brand Management Insights and Opportunities (pp. 1-24).

Khodadady, E., and M. Natanzi. 2012. Designing and validating a scale measuring cultural capitals of Iranian university students majoring in English. Theory and Practice in Language Studies 2 (8): 1627.

Kline, R.B. 2015. Principles and Practice of Structural Equation Modeling, Fourth Edition: Guilford Publications.

Ko, E., J.P. Costello, and C.R. Taylor. 2017. What is a luxury brand? A new definition and review of the literature. Journal of Business Research. doi:https://doi.org/10.1016/j.jbusres.2017.08.023

KPMG. Expectations on luxury goods spending over the next year by Chinese Millennials in 2017. Statista - The Statistics Portal: Statista.

Leibenstein, H. 1950. Bandwagon, Snob, and Veblen effects in the theory of consumers' demand. The Quarterly Journal of Economics 64 (2): 183-207. https://doi.org/10.2307/1882692.

Lewis, A., and M. Moital. 2016. Young professionals' conspicuous consumption of clothing. Journal of Fashion Marketing and Management: An International Journal 20 (2): 138-156. https://doi. org/10.1108/JFMM-04-2015-0034.

Loureiro, S.M.C., J. Jiménez-Barreto, and J. Romero. 2020. Enhancing brand coolness through perceived luxury values: Insight from luxury fashion brands. Journal of Retailing and Consumer Services, 57(May). https://doi.org/10.1016/j.jretconser.2020.102211

Makkar, M., and S.-F. Yap. 2018a. The anatomy of the inconspicuous luxury fashion experience. Journal of Fashion Marketing and Management: An International Journal 22 (1): 129-156. https:// doi.org/10.1108/JFMM-08-2017-0083.

Makkar, M., and S.-F. Yap. 2018b. Emotional experiences behind the pursuit of inconspicuous luxury. Journal of Retailing and Consumer Services 44: 222-234. https://doi.org/10.1016/j.jretconser. 2018.07.001.

Markus, H.R., and S. Kitayama. 1991. Culture and the self: Implications for cognition, emotion, and motivation. Psychological Review 98 (2): 224.

Miller, D. 2005. Consumption studies as the transformation of anthropology Acknowledging consumption, pp. 271-300. London: Routledge.

Miller, K.W., and M.K. Mills. 2012. Contributing clarity by examining brand luxury in the fashion market. Journal of Business Research 65 (10): 1471-1479. https://doi.org/10.1016/j.jbusres. 2011.10.013.

Montgolfier, C. D. A. F. L. M.-A. K. J. d. 2017. The New Luxury Consumer: Why Responding to the Millennial Mindset Will Be Key. Retrieved from https://www.bain.com/insights/luxury-goodsworldwide-market-study-fall-winter-2017/

Nueno, J.L., and J.A. Quelch. 1998. The mass marketing of luxury. Business Horizons 41 (6): 61-61.

Park, C.W., and V.P. Lessig. 1977. Students and Housewives: Differences in Susceptibility to Reference Group Influence. Journal of Consumer Research 4 (2): 102-110.

Piron, F. 2000. Consumers' perceptions of the country-of-origin effect on purchasing intentions of (in)conspicuous products. Journal of 
Consumer Marketing 17 (4): 308-321. https://doi.org/10.1108/ 07363760010335330.

Ringle, C.M., S. Wende, and J.-M. Becker. 2015. SmartPLS 3. Boenningstedt: SmartPLS GmbH, http://www.smartpls.com.

Sarstedt, M., J. Henseler, and C.M. Ringle. 2011. Multigroup analysis in partial least squares (PLS) path modeling: Alternative methods and empirical results Measurement and research methods in international marketing (pp. 195-218): Emerald Group Publishing Limited.

Shao, W., D. Grace, and M. Ross. 2019a. Consumer motivation and luxury consumption: Testing moderating effects. Journal of Retailing and Consumer Services 46: 33-44. https://doi.org/10. 1016/j.jretconser.2018.10.003.

Shao, W., D. Grace, and M. Ross. 2019b. Investigating brand visibility in luxury consumption. Journal of Retailing and Consumer Services 49: 357-370. https://doi.org/10.1016/j.jretconser.2019. 04.017.

Shaw, D.S., and I. Clarke. 1998. Culture, consumption and choice: Towards a conceptual relationship. Journal of Consumer Studies and Home Economics 22 (3): 163-168.

Sheth, J.N., B.I. Newman, and B.L. Gross. 1991. Why We Buy What We Buy: A Theory of Consumption Values: Discovery Service for Air Force Institute of Technology. Journal of Business Research 22 (2): $159-170$.

SmartPLS. Discriminant Validity Assessment. Retrieved from https:// www.smartpls.com/documentation/algorithms-and-techniques/ discriminant-validity-assessment

Snyder, C.R., and H.L. Fromkin. 1980. Uniqueness: The human pursuit of difference. New York: Plenum Press.

Sohu. Annual growth rate of the luxury goods sales in China between 2012 and 2021. Statista: Statista.

Souiden, N., B. M'Saad, and F. Pons. 2011. A cross-cultural analysis of consumers' conspicuous consumption of branded fashion accessories. Journal of International Consumer Marketing 23 (5): 329-343.

Tian, Kelly T., William O. Bearden, and Gary L. Hunter. 2001. Consumers' Need for Uniqueness: Scale Development and Validation. Journal of Consumer Research 28 (1): 50-66. https://doi.org/10. 1086/321947.

Veblen, T. 1992. The Theory of the Leisure Class: An Economic Study of Institutions (1 ed.).

Wei, Y., B. Bergiel, and L. Song. 2019. Effects of parental cultural capital on purchase intention of cognac. International Journal of Wine Business Research 31: 2

Weinberger, M.F., J.R. Zavisca, and J.M. Silva. 2017. Consuming for an imagined future: Middle-class consumer lifestyle and exploratory experiences in the transition to adulthood. Journal of Consumer Research 44 (2): 332-360.

Wiedmann, K.-P., N. Hennigs, and A. Siebels. 2007a. Measuring consumers' luxury value perception: A cross-cultural framework (Vol. 7).

Wiedmann, K.-P., N. Hennigs, and A. Siebels. 2007b. Measuring consumers' luxury value perception: A cross-cultural framework. Academy of Marketing Science Review 2007: 1.

Willersdorf, S., J.1. Hazan, G. Ricci, A. Prénaud, F. Bianchi, J. Seara, and V. Yang. 2020. A New Era And A New Look For Luxury. Retrieved from https://www.bcg.com/publications/2020/ new-era-and-new-look-for-luxury.
Wilson, J.A.J. 2014. Inconspicuous branded consumption is the new business buzzword in retail. Retrieved from https://www.huffi ngtonpost.co.uk/jonathan-aj-wilson/inconspicuous-brandedcon_b_4734255.html?guccounter=1

Wong, N., and A. Ahuvia, A. 1998. Personal taste and family face: Luxury consumption in Confucian and Western societies (Vol. 15).

Wu, M.-S.S., C.-H.S. Chen, and B. Nguyen. 2015. Luxury brand purchases and the extended self: A cross-cultural comparison of young female consumers in Taiwan and the UK. Asia-Pacific Journal of Business Administration 7 (3): 153-173. https://doi. org/10.1108/APJBA-05-2015-0046.

Wu, Z.L., and J. Borgerson. 2017. Forms of inconspicuous consumption: what drives inconspicuous luxury consumption in China? Marketing Theory 17 (4): 491-516.

Publisher's Note Springer Nature remains neutral with regard to jurisdictional claims in published maps and institutional affiliations.

Amélia Maria Pinto da Cunha Brandão is graduated in Enterprises Management and holds a master degree in Finance from the Universidade Portucalense Infante D. Henrique. She has a Ph.D. graduation at the Faculdade de Economia do Porto (FEP) in Brand Management valuation. Presently she is Services Management Master Director at FEP, member of the board of the investigation center CEF.UP and PostGraduate Programme Director at Porto Business School (PBS). She is senior lecturer of Marketing and Brand Management subjects at FEP, since 2004. She is Scientific Committee member of the International Journal of Marketing, Communication and New Media and Master thesis' referee reviewer, Higher School of Economics, St. Petersburg. Her previous work experience was in marketing and brand communication consultancy. She was coordinator and trainer for various projects and was senior consultant in micro enterprises. She was Supervisor of Work Placements and Assistant Teacher at Universidade Portucalense Infante D. Henrique, 1995-2005. She is author of many book chapters in marketing and communication fields. Has a Ph.D. degree from the Faculdade de Economia do Porto (FEP) in the Brand Management valuation. Presently, she is the Services Management Master Director at FEP.UP, PostGraduate Programme Director at Porto Business School (PBS). She is senior lecturer of Marketing and Brand Management subjects at FEP, since 2004. Additionally, she is teaching Managerial Communication, Strategy Communication, and Marketing at Faculdade de Letras da Universidade do Porto, since 2008. She is Scientific Committee member of the International Journal of Marketing, Communication, and New Media. She is book author. Her previous work experience was in brand communication consultancy at Associação Nacional de Jovens Empresários (ANJE), Associação Empresarial de Portugal (AEP), Markamos and XZ Consultores. She has been a coordinator and trainer for various projects and was senior consultant in micro enterprises (Formação e Ação em Micro Empresas -Fame project). She was Supervisor of Work Placements and Assistant Teacher at Universidade Portucalense Infante D. Henrique, 1995-2005, in undergraduate course, of Managerial Communication, Marketing Research, Brand Management and Marketing Management subjects. From 2000 to 2004 she was Visiting Assistant Teacher at Faculdad de Ciencias Economicas y Empresariales, Universidad de Sevilla, in Marketing Undergraduate course. 